\title{
Assessment of Social Vulnerability to Kiematubu Volcano in Tidore Island, North Maluku
}

\author{
Widiyana Riasasi ${ }^{1}$, Muh Aris Marfai ${ }^{2,3}$, Bachtiar W Mutaqin ${ }^{2, *}$ Danang Sri Hadmoko ${ }^{2}$, Franck Lavigne ${ }^{4}$, Audrey Faral ${ }^{4}$, \\ and Helvetia Wijayanti ${ }^{2}$ \\ ${ }^{1}$ Geography Department, Universitas Amikom Yogyakarta, 55281 Sleman, Indonesia \\ ${ }^{2}$ Coastal and Watershed Research Group, Faculty of Geography, Universitas Gadjah Mada, 55281 Bulaksumur, Indonesia \\ ${ }^{3}$ Geospatial Information Agency, 16911 Cibinong, Indonesia \\ ${ }^{4}$ Université Paris 1 Panthéon Sorbonne, Laboratoire de Géographie Physique UMR 8591, 92190 Meudon, France
}

\begin{abstract}
Kiematubu volcano is often considered as non-volcanic, even though it consists of basalt material, since it has never erupted before. In fact, that small volcanic islands have a high risk due to their restriction on means and resources. The study aims to assess the social vulnerability of the community in Tidore Island that may be exposed to the eruption of the Kiematubu volcano. There has not been previous research in Tidore Island regarding volcanic vulnerability yet. The social vulnerability is an initial assessment of disaster management, which will affect in optimizing community's capacity then minimizing the disaster impacts. Social parameter of demographic condition, health facilities, and education facilities was weighted to assess social vulnerability. The result shows that the social vulnerability class of Tidore Island is dominantly low, approximately $80 \%$, the rest is middle and high, with a percentage of $13 \%$ and $7 \%$, respectively. Mostly, the low vulnerable villages are due to less population density. However, the highly vulnerable villages, Gamtufkange and Indonesiana, consist of very high and high population density. The southeast part of Tidore Island, where both villages are situated, is the center of human activities, such as governmental, trades, and education.
\end{abstract}

\section{Introduction}

Indonesia's location lying on the ring of fire causes volcanic range formation (Figure 1). Moreover, Indonesia is also known as an archipelagic country, which consists of more than 17,000 islands. Aside from flood, earthquake, land subsidence, or landslide, a volcanic eruption is a natural disaster that frequently occurred in Indonesia because the active volcanoes are scattered in major (Sumatera, Java, Sulawesi) and small islands near Maluku, Nusa Tenggara, Halmahera) [1,2].

Maluku Kepulauan is situated in the eastern part of Indonesia with many small islands and has active volcanoes due to the location precisely on the subduction area of Eurasia and Indo-Australia tectonic plates. Gamalama volcano in Ternate, Gamkonora and Ibu volcanoes in West Halmahera, and Dukono volcano in North Halmahera had advisory (waspada) stage in 2017 [3]. Gamalama volcano is the most active one that had occurred 77 times eruption since 1510 [4].

Ternate is a small island with a population density of more than 200,000 in an area of $111.4 \mathrm{~km}^{2}$. It makes the population has a high vulnerability to eruption hazard. At the southeast part of Ternate, lay a small island called Tidore with a $1,550 \mathrm{~km}^{2}$ area. The island is part of Tidore Kepulauan municipality, with Kiematubu volcano situated in the center of the Tidore region. Kiematubu volcano has the highest summit of 1,730 meters in Maluku.

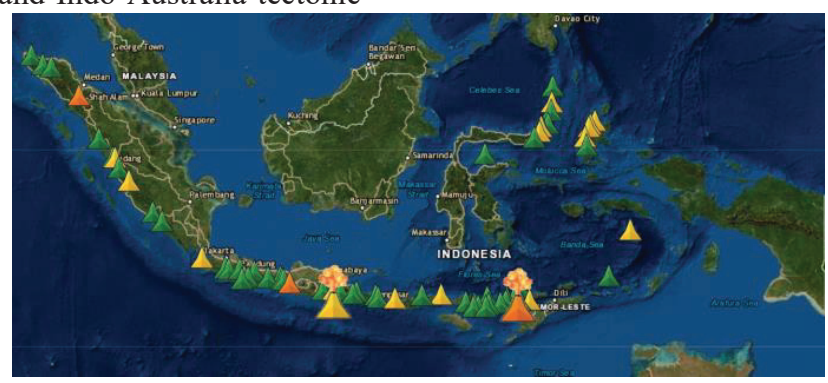

Fig. 1. Volcanic range formation in Indonesia. Different color means different status for each volcano from green (normal) to red (warning) (Courtesy: MAGMA Indonesia, 2021).

\footnotetext{
* Corresponding author: mutaqin@ugm.ac.id
} 
Despite having various beneficiaries of natural resources, such as agriculture, livestock, and tourism, the volcano also has a potential hazard, such as eruption and its post-disaster hazard, i.e., famine, epidemic disease, or lahar $[5,6]$. Inhabitant living in small volcanic islands has a higher risk of being exposed to eruption disaster than those living in major islands. Kiematubu volcano has never erupted in history, nevertheless according to the first ascent expedition by C.G.C. Reinwardth in 1821, found that the material of the volcano was basalt [7]. The only tectonic disaster in history based on previous historical records by the Dutch scientists that had been occurred earthquake with violent shocks in 1855 in Ternate and Tidore. It caused 25 houses to collapse and 24 fatalities due to blocks of rock sliding from a hill in Tidore [7].

Even though the Kiematubu volcano is considered at a rest-phase stage, eruption's potential still exists. Inhabitant that lives in potential hazard area is vulnerable, mostly the poor, gender minorities, the disabled, the elderly, and those who are unable to access safety resource [8,9]. Restriction to access resources, i.e., transportation, communication, and limited natural resources, often becomes an obstacle in regional development in a small island $[4,10]$, including in terms of disaster management.
Disaster risk reduction requires improvement in community capacity. To improve the capacity, it is necessary to measure the level of vulnerability in the potential hazard area. There are several types of vulnerabilities to assess the disaster risk, such as physical, economic, and social elements. Social vulnerability tends to be a multidimensional concept because there is no agreement about social vulnerability within the social science community [11]. Approaches were implemented to assess the social vulnerability using indicators to identify the traits of a community on responding hazard. This research aims to assess the social vulnerability of the community in Tidore Island that may be exposed to the eruption of the Kiematubu volcano.

\section{Methods}

Administratively, Tidore Kepulauan municipality is part of North Maluku province. Its area scatters in three different islands, namely Tidore Island, Mare Island, and Halmahera Island. However, the study particularly assessed Tidore Island, where the Kiematubu volcano is situated (Figure 2). There are 31 villages' lies on Tidore Island, which is included in four sub districts.

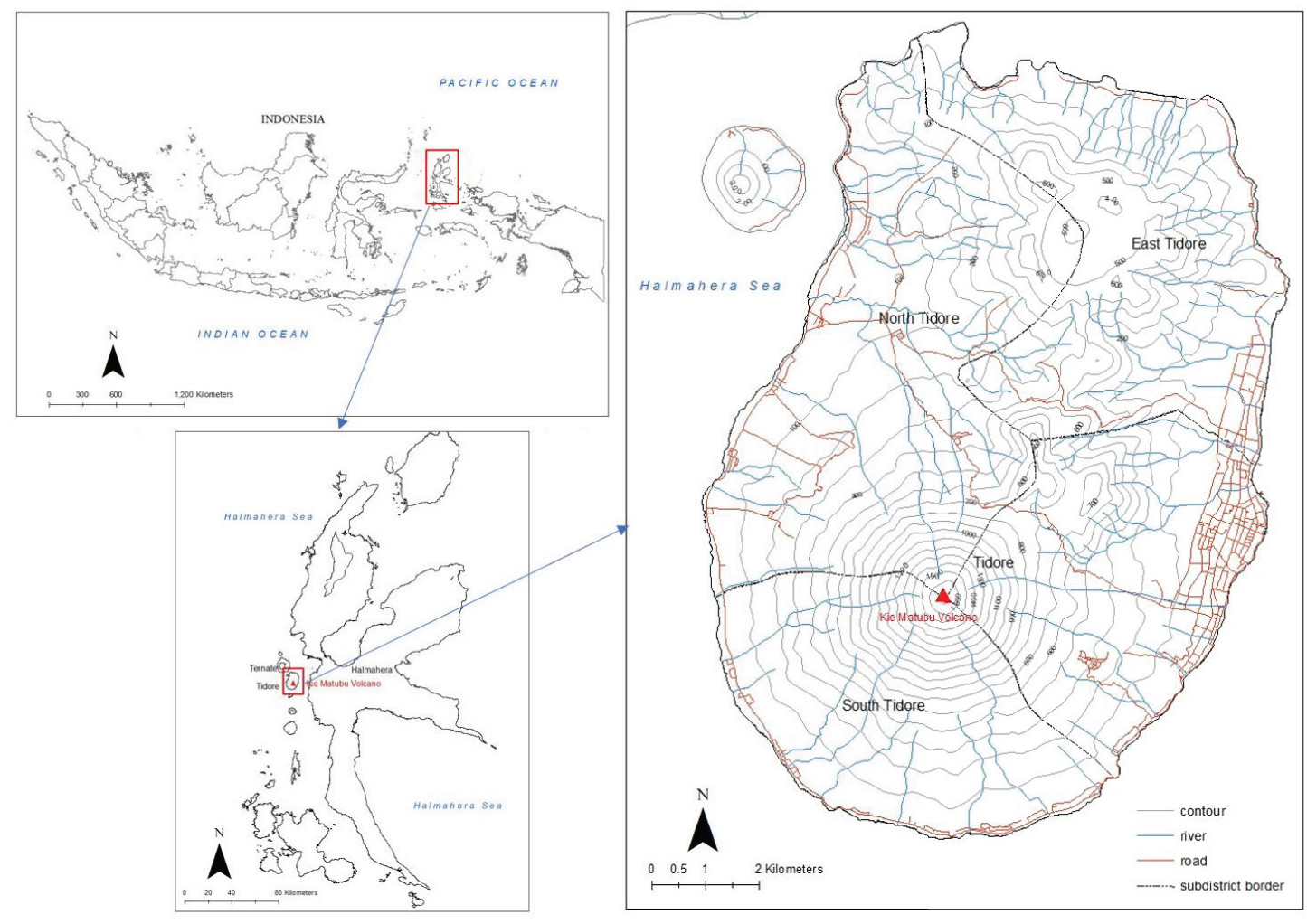

Fig. 2. Administrative map of Tidore Island.

Tidore Kepulauan municipality data in 2020 was employed along with spatial data of topographical maps and high-resolution satellite imagery data. Some parameters to access social vulnerability consist of demographic condition, education and knowledge, health, institution, and social insurance [2,11]. Detailed variables of each parameter are shown in Table 1 . Assessment of social vulnerability used the village as the unit of analysis. 
Table 1. Parameters of social vulnerability assessment, modified from Ref. [2,11].

\begin{tabular}{|c|c|}
\hline Parameter & Variable \\
\hline $\begin{array}{c}\text { Demographic } \\
\text { Condition }\end{array}$ & Population density \\
\hline $\begin{array}{c}\text { Education and } \\
\text { Knowledge }\end{array}$ & $\begin{array}{c}\text { Number of the formal institution } \\
\text { (elementary) }\end{array}$ \\
\hline Health & $\begin{array}{c}\text { Number of health facilities } \\
\text { (hospital) }\end{array}$ \\
\hline
\end{tabular}

Variable of education and knowledge indicated the number of an existing elementary school in a village. Elementary school is a stage of education with basic knowledge, such as writing and reading. The least capacity of the human to coordinate in emergency or crisis situations is understood and capable of reading and writing. The health parameter used the number of health facilities, particularly hospitals. The existence of a hospital is important, especially in the response stage when a disaster occurred.

The variable was weighted based on its level of impact affected by the hazard. The existence of education institutions will increase community capacity; therefore, the village has a school was weighted 1 . If the school does not exist, weighted 0. A similar process was employed to the existence of a hospital in the village. According to the National Standard of Indonesia, it divided the category into four in the case of population density [12], as presented in Table 2 .

Table 2. Category of population density, modified from the National Standard of Indonesia.

\begin{tabular}{|c|c|c|}
\hline Category & $\begin{array}{c}\text { Population density } \\
\text { (population/hectare) }\end{array}$ & Weight \\
\hline Low & $<150$ & 3 \\
\hline Middle & $151-200$ & 2 \\
\hline High & $201-400$ & 1 \\
\hline Very high & $>400$ & 0 \\
\hline
\end{tabular}

Statistic calculation was performed to determine social vulnerability class - furthermore, the highest total value of all variables minus the lowest value equal to the class range. Moreover, the range was divided into three social vulnerability classes: low, middle, and high. The bigger number of weights, the higher class of vulnerability. Weights of social vulnerability are shown in Table 3.

Table 3. Social vulnerability class.

\begin{tabular}{|c|c|}
\hline Total Weights & Vulnerability Class \\
\hline $0-1$ & Low \\
\hline $2-3$ & Middle \\
\hline $4-5$ & High \\
\hline
\end{tabular}

\section{Results and discussion}

Vulnerability defines a characteristic or circumstance of a community, structure, assets, or system that is susceptible to be damaged or disrupted by a hazard, or simply means as the potential for loss $[11,13,14]$. The measurement of vulnerability cannot be precise because various perspectives determine the subject/object, which is multidimensional and differential, scale-dependent, and dynamic $[15,16]$. However, the most recognized approach to assess vulnerability consists of five dimensions: physical/functional, economic, social, environmental, and political/institutional [17].

The study mainly focused on assessing social vulnerability due to potential hazards of Kiematubu volcano, using secondary data of Tidore Kepulauan municipality in 2020, and employing Geographic Information System (GIS) as the tools. The result shows that the social vulnerability class of Tidore Island is dominantly low, approximately $80 \%$, the rest is middle and high, with a percentage of $13 \%$ and $7 \%$, respectively. Detail social vulnerability class of the village is shown in Table 4.

Table 4. Social vulnerability of Tidore Island.

\begin{tabular}{|c|c|c|}
\hline Sub district & Village & Class \\
\hline North Tidore & Afa Afa & low \\
\hline South Tidore & Dokiri & low \\
\hline East Tidore & Dowora & low \\
\hline Tidore & Folarora & low \\
\hline Tidore & Goto & low \\
\hline North Tidore & Gubu Kusuma & low \\
\hline Tidore & Gura-Bunga & low \\
\hline North Tidore & Jaya & low \\
\hline East Tidore & Kalaodi & low \\
\hline East Tidore & Mafututu & low \\
\hline North Tidore & Mareku & low \\
\hline North Tidore & Ome & low \\
\hline North Tidore & Rum & low \\
\hline North Tidore & Rum Balibunga & low \\
\hline North Tidore & Sirongo Folaraha & low \\
\hline Tidore & Soa Sio & low \\
\hline Tidore & Soadara & low \\
\hline South Tidore & Toloa & low \\
\hline Tidore & Tomagoba & low \\
\hline South Tidore & Tomalou & low \\
\hline South Tidore & Tongowai & low \\
\hline Tidore & Topo & low \\
\hline Tidore & Topo Tiga & low \\
\hline East Tidore & Tosa & low \\
\hline South Tidore & Tuguiha & low \\
\hline North Tidore & Bobo & middle \\
\hline North Tidore & Fobaharu & middle \\
\hline South Tidore & Gurabati & middle \\
\hline Tidore & Seli & middle \\
\hline Tidore & Gamtufkange & high \\
\hline Tidore & Indonesiana & high \\
\hline
\end{tabular}


Mostly, the low vulnerable villages are due to less population density. However, the highly vulnerable villages, Gamtufkange and Indonesiana, consist of very high and high population density. The southeast part of Tidore Island is the center of human activities, such as governmental, trades, and education, where both villages are situated. There are two universities located in Gamtufkange. Notwithstanding, health and education facilities do not exist in those villages. The map of the vulnerability class can be seen in Figure 3.

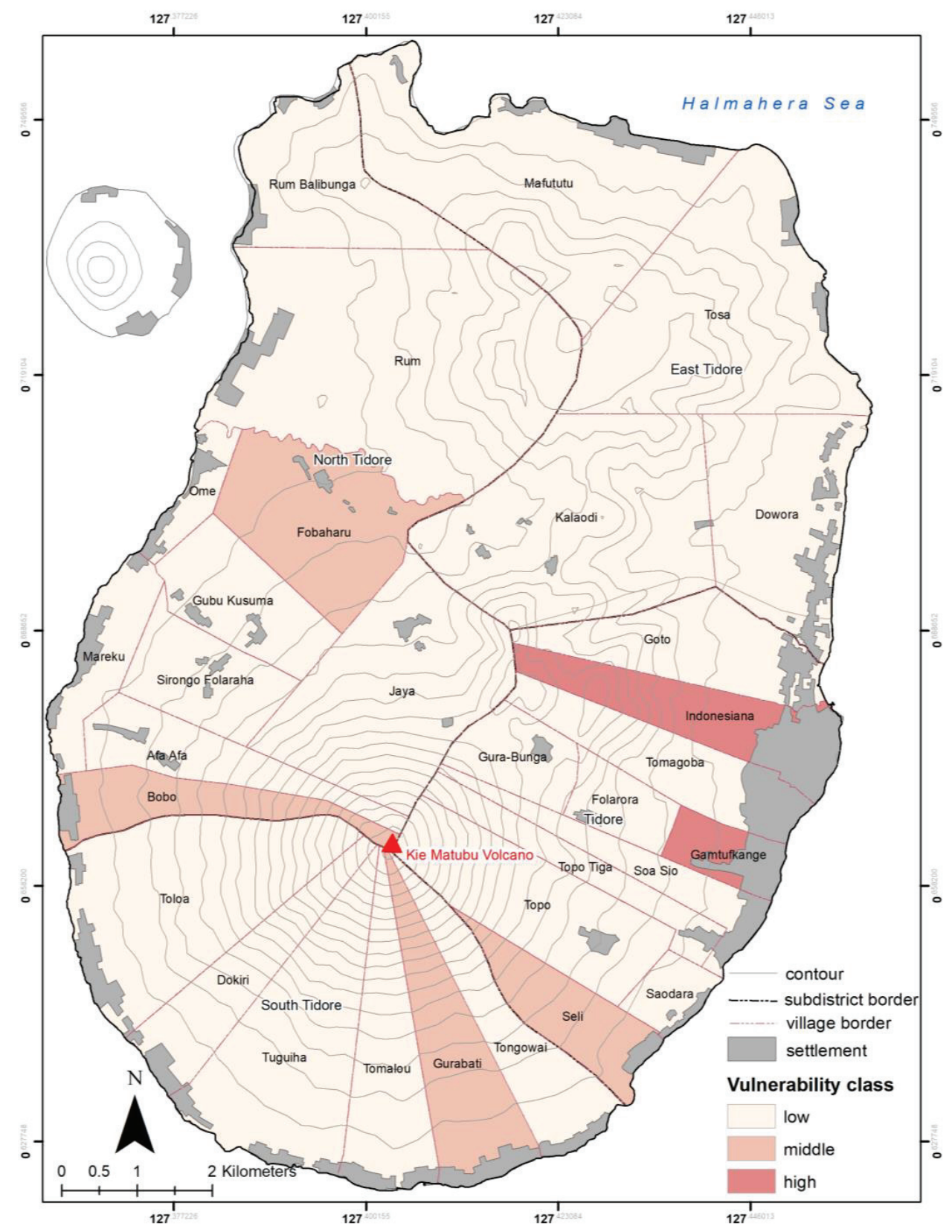

Fig. 3. Social vulnerability map of Tidore Island.

Nevertheless, disaster preparedness in Tidore Island has been quite good because each subdistrict has a health facility (hospital). The South Tidore subdistrict has a hospital in Tomalou, the North Tidore's hospital is in Ome, the East Tidore's is in Tosa, and the Tidore subdistrict's hospital is in Tomagoba village.
Meanwhile, education facility of elementary school exists in most villages of the island.

To reduce the risk of disaster, it is necessary to minimize the vulnerability and optimize the community's capacity that is potentially affected by the disaster. Regardless, the Kiematubu volcano has never erupted in history, and disaster preparedness is still 
necessary to minimize the impacts of a future eruption. As in Sendai Framework for disaster risk reduction, enhance disaster preparedness for effective response is stated as one of the priorities for action [18].

Social vulnerability assessment is more focused on measuring the social facilities' aspects against potential disaster. Hence, the supporting aspects must be advanced to reduce vulnerability, such as improving health facilities service and effectively developing education facilities. Assessment of social vulnerability occupied the second rank based on the research in Gamalama volcano conducted by Ref. [2], after economic vulnerability, then followed by the physical vulnerability.

Collaboration with its stakeholders is an integral part of vulnerability assessment because it aims to reduce vulnerability by enhancing the lack and fixing the existing [19]. As a small island, Tidore faces different challenges in disaster management compared to major islands, such as the evacuation scenario or access to resources. On the disaster management, the government of Indonesia has established the National Agency for Disaster Management (BNPB) at the national level and the Local Agency for Disaster Management (BPBD) at the province and regency levels. Therefore, all stakeholders, including the community and scientists, need to be integrated into disaster risk reduction action [20].

\section{Conclusions}

Based on the assessment of the social vulnerability to the Kiematubu volcano in Tidore Island, most villages are categorized as low vulnerable. Indonesiana and Gamtufkange village are classified as having a high social vulnerability, that both are the center of human activities in Tidore Island. Kiematubu volcano has never erupted before; nonetheless, disaster preparedness is necessary to minimize disaster risk.

The study was initial research for the social vulnerability of the Kiematubu volcano. Further social vulnerability with a more comprehensive parameter should be assessed to get more valid information that will be useful for the community and related stakeholders to reduce the social vulnerability. Furthermore, companies with other vulnerabilities, i.e., economy and physical vulnerability, assessment of vulnerability in all aspects will complete the assessment to formulate disaster risk reduction.

This research was funded by the grant of National Basic Research from the Indonesian Ministry of Research, Technology and Higher Education - GASTROPODE Project. We thank anonymous reviewers for their constructive comments on the manuscript. The authors also acknowledge the Regional Disaster Management Agency of North Maluku.

\section{References}

1. M.A. Marfai, L. King, L.P. Singh, D. Mardiatno, J. Sartohadi, D.S. Hadmoko, A. Dewi. Environmental Geology 56, 2 (2008)
2. E.T.W. Mei, I.M. Sari, A. Fajarwati, D. Safitri. Assessing the Social Economic and Physical Vulnerabilities to Gamalama Volcano, in Proceedings of the 1st International Conference on Geography and Education, 29 October 2016, Malang, Indonesia (2016)

3. B. Nurgianto. Empat Gunung Berapi di Maluku Utara Berstatus Waspada, https://nasional.tempo.co/read/881559/empatgunung-berapi-di-maluku-utara-berstatus-waspada (accessed on 20 May 2021)

4. A. Hidayat, M.A. Marfai, D.S. Hadmoko. International Journal of Geomate 18, 66 (2020)

5. E.T.W. Mei, A. Harijoko, N.I. Setiawan, H. Wijayanti, W. Riasasi. IOP Conference Series: Earth and Environmental Science 412012012 (2020)

6. C.J. Tanguy, C. Ribière, A. Scarth, W. Tjetjep. Bull Volcanol. 60 (1998)

7. A. Wichmann. KNAW Proceedings 21 (1919)

8. B. Balgos, J.C. Gaillard, K. Sanz. Gender and Development 20, 2 (2012)

9. E.T.W. Mei, F. Lavigne. Geological Society Special Publication 361, 1 (2012)

10. E. Wilkinson, E. Lovell, B. Carby, J. Barclay, R.E.A. Robertson. Resources 5, 21 (2016)

11. S.L. Cutter, B.J. Boruff, L.W. Shirley. Social Science Quarterly 84, 2 (2003)

12. National Standard of Indonesia. Tata cara perencanaan lingkungan perumahan di perkotaan. SNI 03-1733-2004 (2004)

13. H. Khan, L.G. Vasilescu, A. Khan. Management and Marketing Journal 6, 1 (2008)

14. UNISDR. UNISDR Terminology on disaster risk reduction (2009)

15. C. Vogel, K. O'Brien. Bulletin on Global Environmental Change and Human Security 13 (2004)

16. J. Birkmann. Indicators and criteria for measuring vulnerability: theoretical basis and requirements, in Measuring vulnerability to natural hazards towards disaster resilient societies (2006)

17. R. Ciurean, D. Schröter, T. Glade. Conceptual Frameworks of Vulnerability Assessments for Natural Disasters Reduction, in Approaches to Disaster Management - Examining the Implications of Hazards, Emergencies, and Disasters (2013)

18. UNISDR. Sendai Framework for Disaster Risk Reduction 2015-2030 (2015)

19. D. Schröter. Vulnerability to changes in ecosystem services, in Assessing Vulnerability to Global Environmental Change - Making Research Useful for Adaptation Decision Making and Policy (2005)

20. F. Lavigne, V. Jean, Suwardji, Kusnadi, Hiden, Edong, Syamsuddin, M. Reghezza-Zitt, B.W. Mutaqin, M.N. Malawani. Earthquakes and tsunamis in Lombok, NTB: from hazard assessment to crisis management $\mathbf{1}$ (2020) 